\title{
Production and Characterization of Monoclonal Antibodies Anti Fragment Fc of Bovine IgG
}

\author{
Tânia Regina Penha ${ }^{1 *}$, Ernesto Renato Krüger ${ }^{2}$, Vanete Thomaz-Soccol ${ }^{3}$, Jorge Victor \\ Bacila Agottani ${ }^{1}$, Flávio Hiroshi Itano ${ }^{1}$, Ludmilla Della Coletta Troiano ${ }^{1}$ and Josiane \\ Brodzinski ${ }^{1}$ \\ ${ }^{1}$ Instituto de Tecnologia do Paraná; Rua João Américo de Oliveira, 330; Curitiba - PR - Brasil. ${ }^{2}$ Centro de \\ Diagnóstico Marcos Enrietti; Curitiba - PR - Brasil. ${ }^{3}$ Universidade Federal do Paraná; Curitiba - PR - Brasil
}

\begin{abstract}
The aim of this work was to produce and characterize monoclonal antibodies anti bovine immunoglobulin $G$ (IgG). Out of seven hybridomas, two were chosen based on the ELISA'S absorbance values and were labeled B4F11 and B3H12. These monoclonals were analyzed through Western Blot for IgG fragments obtained by proteolysis with papain, separated by electrophoresis in polyacrylamide gel electrophoresis with $\beta$-mercaptoetanol as reducing agent. This revealed that, possibly, the B4F11 was directed to a conformational antigen, and that B3H12 reacted in a specific fashion with Fc (Bovine IgG crystallizable fragment). This antibody could be used in the development of reagents to immunoassays relevant for research and diagnosis.
\end{abstract}

Key words: Monoclonal antibodies; bovine immunoglobulin G; Fragment Fc

\section{INTRODUCTION}

Biotechnology is currently considered the newest advance in the life sciences. This field became widely known at the end of the twentieth century, affecting various areas of research in human life and the environment. Recent progress in molecular biology and cell knowledge has made it possible to produce recombining DNA molecules with different applications in the production of protein of interest. Areas of animal health that have been greatly improved by biotechnology are: the development of diagnostic test for disease control, vaccine production, nutrition and parasite control. The production of antibodies for specific immunogens fostered by precise protocols of immunization has allowed the development of highly specific reagents to be used as diagnostic tools. These antibodies may be of polyclonal or monoclonal origin, the latter having some advantages over the former due to their high specificity and production by immortalized cells. Monoclonal antibodies are used in immunoassays, which are extremely specific and sensitive to a great variety of viruses, bacteria, protozoa, and macro-parasitic components. The specificity of the test overcomes any restriction concerning the nature of the target material under evaluation. The remarkable sensitivity allows the identification of extremely small quantities of the target component, as small as $10^{-12}$.

To better understand and evaluate the humoral immunity of domestic animals in terms of health or disease, it is essential to isolate, characterize

*Author for correspondence: trpenha@tecpar.br 
and quantify the immunoglobulins, which are the main components of the system that detects invaders in solutions of biological fluids or associated cells of this same medium. The bovine immunoglobulins consist of four classes: IgM, $\mathrm{IgG}$, IgA, and IgE. The IgGs contain three subclasses: $\operatorname{IgG1}, \operatorname{IgG} 2$, and $\operatorname{IgG} 3$ as well as two light $\lambda$ (lambda) and K (Kappa) chains (Knight et al., 1988; Symons et al., 1989; Kacskovics et al., 1996; Rabbani et al., 1997). The three genes that codify the heavy chains of the IgGs $(\gamma 1, \gamma 2, \gamma 3)$ are located in the chromosome 21q24 (Gu et al., 1992). The production of monoclonal antibodies allows the development of specific laboratory tests for each class as well as each subclass. So far, no protein or mRNA has been identified for the $\operatorname{IgD}$ class. For the light chains, more than $90 \%$ are 2 (lambda); however, as no specific reagents to either kappa or lambda exist, future studies would have to be carried out in order to establish the relationship between $\lambda$ and $K$ chains (Pastoret, 1998).

The immunoglobulins make up the largest portion of the humoral immunity, of which IgG is the main class of antibodies present in the blood, lymph, peritoneal, and cerebro-spinal fluids. They also constitute $75 \%$ of serum immunoglobulins. Subclasses of IgG exist in different species and their biochemical composition offers the basis for the biological effectors' functions. The molecular and serological characteristics of the bovine $\mathrm{IgG}$ subclasses show the existence of allotype variation, providing polymorphic genetic markers for immunoglobulins with functional consequences (Blakeslee et al., 1971; Rapacz et al., 1972; Wegrezyn et al., 1978; Symons et al., 1989; Kacskovics et al., 1996; Rabbani et al., 1997).

The IgG1 displays unique characteristics: a) it constitutes $90 \%$ of the colostral immunoglobulins, providing neonatal protection as well as instructions for the action of the immune system. (Butler et al., 1972; Butler et al., 1974; Guidry et al., 1980); b) it is selectively transported by the $\mathrm{FcRn}$, a receptor which is found in the lung alveolar and mammary gland epithelium (Dyxon et al., 1961; Kemler et al., 1965; Brandon et al., $1971)$; c) it binds to neutrophils such as $\mathrm{IgG} 2$ (Mcguire et al., 1979; Butler et al., 1985); d) it is synthesized locally and released as a secretory immunoglobulin on the mucosa (Brandon et al., 1971; Butler et al., 1985). Different allotypes among animals of the same species correspond to the capacity of influencing the immune system and/or creating resistance to viral and bacterial infections. Allotype determinants are found in IgG1 and IgG2 (Saini et al., 2007). The most commonly studied, A1 and A2 are found in the $\mathrm{IgG} 2$ subclass and denominated $\operatorname{IgG} 2^{\mathrm{a}}$ and $\mathrm{IgG}_{2}{ }^{\mathrm{b}}$. The $\operatorname{IgG} 2^{\mathrm{a}}$ allotype manifests before the $\operatorname{IgG} 2^{\mathrm{b}}$ during the development of calves, which is efficient in the activation of complement, an important mechanism in the control of infections by pyogenic bacteria. Proteins synthesized by these bacteria bind to the allotype (b) and not to the allotype (a) (Corbeil et al., 1997; BastidaCorcuera et al., 1999 (b).

The heterogeneous characteristic of $\mathrm{IgG} 2$ was proven additionally by polyclonal and monoclonal antibodies. Human IgG was used in hybridization tests showing that there were three subclasses of bovine IgG. Out of the three bovine genes that code for IgG, the first two ones code for IgG1 and $\mathrm{IgG} 2$, respectively, while the third gene codes for $\mathrm{IgG} 3$, which is not recognized by IgG1 and $\mathrm{IgG} 2$ antiserum. According to the immunoglobulin workshop promoted by the Veterinarian Immunology Committee, the three bovine $\operatorname{IgG}$ subclasses are labeled: IgG1, IgG2 and IgG3. It must be noted that the use of the same nomenclature for the subclasses (IgG1, IgG2, and IgG3) among different species frequently causes the misunderstanding that the subclasses are homologous and have the same function. This is true for $\operatorname{IgM}, \operatorname{IgG}, \operatorname{IgA}, \operatorname{IgD}$, and $\operatorname{IgE}$ but does not apply to the subclasses. Currently, the prevailing hypothesis is that of the derivation of the species preceded the subclasses evolution (Kehoe et al., 1974).

Thus, the present work was developed aiming at producing a monoclonal antibody against bovine $\mathrm{IgG}$ and improving the quality of cattle disease diagnoses.

\section{MATERIAL AND METHODS}

The methodologies used by Hallow et al., (1988) were followed in this work with the modifications and adaptations mentioned in the appropriate sections.

\section{Blood serum}

The serum samples were collected by bleeding the bovine jugular vein, from a herd of the Federal University of Parana farm and the samples were 
sent for examination at the Centro de Diagnóstico Marcos Enrietti, Curitiba-PR-Brazil. A serum pool was made with collected samples, which showed a clear aspect and absence of hemolysis. Later, it was centrifuged at $14,800 \mathrm{~g}$ at $4^{\circ} \mathrm{C}$ for 30 minutes. The supernatant was removed and samples were separated for immunodiffusion and electrophoresis. The rest was stored under $-20^{\circ} \mathrm{C}$ until further use.

\section{Serum lipoproteins removal}

Two procedures were used: the first one was labeled 1 , in which $3.0 \mathrm{~g}$ Polyvinylpyrolidone (PVP) was gradually mixed in $100 \mathrm{ml}$ of serum under stirring at $4^{\circ} \mathrm{C}$ for $4 \mathrm{~h}$. At the end, the serum was centrifuged at $14,800 \mathrm{~g}$ at $4^{\circ} \mathrm{C}$ for 30 minutes. The supernatant was collected and stored at $4^{\circ} \mathrm{C}$ for subsequent stages. In the second procedure, labeled 2, the solution used was $5 \%$ dextran sulfate ( $5 \mathrm{~g}$ of sodium dextran sulfate in $100 \mathrm{~mL}$ of distilled water) added to a proportion of $1.25 \mathrm{~mL}$ for every $25 \mathrm{~mL}$ of serum, adding dropwise under stirring. After that, it was left at room temperature for 30 minutes, being constantly stirred on a 10minute interval basis. Then, $2.25 \mathrm{~mL}$ of $11.1 \%$ calcium chloride solution was taken and added to $25 \mathrm{~mL}$ of serum (dropwise under stirring). The suspension was left on ice bath for 30 minutes and then centrifuged at $14,800 \mathrm{~g}$ at $4^{\circ} \mathrm{C}$ for 30 minutes. After collecting the supernatant, the samples were separated for immunodiffusion and electrophoresis and the rest was stored at $4^{\circ} \mathrm{C}$.

\section{Immunoglobulins precipitation}

After the quantity of serum pre-set had been checked, its volume was doubled with PBS buffer (phosphate buffered saline).To the final volume, serum plus PBS, the same quantity of saturated ammonium sulfate solution was added dropwise ( $761 \mathrm{~g}$ of ammonium sulfate in $1000 \mathrm{~mL}$ of distilled water; $\mathrm{pH}$ 7.2) under stirring at room temperature, which precipitated all the immunoglobulin classes at $50 \%$ concentration. The suspension was homogenized for 30 minutes on a magnetic stirrer, after that it was centrifuged at $14,800 \mathrm{~g}$ at $4^{\circ} \mathrm{C}$ for 30 minutes. The precipitate was recovered and resuspended in PBS to the original serum volume.

\section{Immunoglobulins $\mathbf{G}$ precipitation}

Saturated ammonium sulfate solution was added to achieve $33 \%$ concentration in order to get the IgG precipitation. This saturation was calculated from the immunoglobulin suspension volume, according the protocol presented above. Then, stirring was maintained for 30 minutes at $4^{\circ} \mathrm{C}$ and, after that, centrifuged at $14,800 \mathrm{~g}$ for 30 minutes. The supernatant was kept between 2 and $8^{\circ} \mathrm{C}$; the precipitated $\mathrm{IgG}$ was re-suspended in a $5.0 \mathrm{~mL}$ volume of PBS and dialyzed against PBS for $72 \mathrm{~h}$ with changes each $12 \mathrm{~h}$ at $4^{\circ} \mathrm{C}$.

\section{Dialysis}

The dialysis was run for three days in a flask containing 2-L of PBS, with changes every $12 \mathrm{~h}$. After this, the $G$ immunoglobulins were centrifuged at 3,700g for 15 minutes to remove the impurities. From the dialyzed IgG solution, samples were collected to measure the protein content and to perform the immunodiffusion and electrophoresis, and the rest was stored at $-80^{\circ} \mathrm{C}$.

\section{Quantification of proteins}

A physical method employing metrolab 1700 spectrophotometer, wavelenght set at 260 and $280 \mathrm{~nm}$ was used. The results were obtained according to the following formula:

$\mathrm{Y}=(1.55 \times 280 \mathrm{~nm}$ readings $)-(0.76 \times 260 \mathrm{~nm}$ readings)

$\mathrm{Y}$ value $\mathrm{x}$ used dilution $=$ protein concentration in $\mathrm{mg} / \mathrm{mL}$.

\section{IgG Purification}

Affinity chromatography column sensitized with protein $\mathrm{G}$ from Staphylococcus aureus, at draining speed of $1 \mathrm{~mL} / \mathrm{min}$ (Hitrap G HT, Amershan) was used. The column was balanced with 10 volumes of adsorption buffer ( $20 \mathrm{mM}$ of sodium phosphate, $\mathrm{pH}$ 7.0). After that, the sample was applied to a $1.0 \mathrm{~mL}$ volume. Then, the column was washed with 10 column volumes of adsorption buffer, until there was no more protein detected at 280 $\mathrm{nm}$. The material was eluted by the use of a fivecolumn volume of elution buffer, $(0.1 \mathrm{M}$ glycine$\mathrm{HCl}, \mathrm{pH} 2.7$ ). From every $1.0 \mathrm{~mL}$ fraction, a $50 \mu \mathrm{l}$ sample was submitted to a test with $10 \%$ trichloroacetic acid. Highly concentrated samples, with intense turbidity, were saved. To each fraction, $100 \mu \mathrm{L}$ of neutral buffer was added $(1 \mathrm{M}$ of TRIS-HCl, $\mathrm{pH}$ 9.0). The column was washed with 10 volumes of adsorption buffer and conserved with ethanol at $20 \%(20 \mathrm{~mL}$ of ethanol in $80 \mathrm{~mL}$ of distilled water) at $4^{\circ} \mathrm{C}$.

\section{Mice immunization protocol}

For the first dose, each mouse was immunized with an emulsion of $50 \mu \mathrm{g}$ of protein and $50 \%$ of Freund's complete adjuvant in a final volume of 
$100 \mu \mathrm{L}$. The emulsion, antigen plus adjuvant, was homogenized until there was no water drop formation during the rest, or until there was no drop dissolution when it was poured over the water surface in the recipient. The emulsions containing bovine IgG were inoculated in a group of 10 mice via intra-peritoneal. The second and third doses were given at a 15-day interval and were processed like the first one. The adjuvant was replaced by Freund's incomplete. At the end of the immunizations, total blood was collected from one mouse from each allotment through cardiac puncture and the serum was separated from the blood clot in order to evaluate the humoral immune response, through an immunodiffusion test. All mice were kept in constant surveillance during the execution of the immunization protocol.

\section{Humoral immunity evaluation through immunodiffusion}

A six-centimeter diameter Petry dish, containing $7.0 \mathrm{~mL}$ of $0.9 \%$ agar in PBS was used. The diameter of each well and the distance between them was 3 and $4 \mathrm{~mm}$, respectively. Then the purified bovine $\operatorname{IgG}(25 \mu \mathrm{L})$ was added in the central well. In the peripheral wells, $25 \mu \mathrm{L}$ of bovine $\mathrm{IgG}$ immunized and non-immunized mouse serum was added alternately. The dishes were incubated in a humidity chamber at $28^{\circ} \mathrm{C}$ for $48 \mathrm{~h}$. The reading and interpretation obeyed the criteria of precipitation lines between the purified bovine IgG and immunized animal serum and no lines formed with negative serum.

\section{Peritoneal macrophages}

Twenty-four hours before fusion, peritoneal macrophages from five non-immunized mice were harvested through washing the peritoneal cavity with $0.34 \mathrm{M}$ sucrose in order to maintain the isotonicity. Then the skin from the mice abdomen was opened without drilling the peritoneal membrane. Five milliliters of sucrose solution were injected into the peritoneal cavity and the abdomen was massaged to release the macrophages; then the solution was removed. The cell suspension was centrifuged at $800 \mathrm{~g}$ for 15 minutes at $4^{\circ} \mathrm{C}$; the supernatant was discarded and the cell pellet was re-suspended with $10 \mathrm{~mL}$ of RPMI culture medium. A sample of the macrophage suspension was diluted to 1:20 proportion and counted in a Fuchs-Rosenthal chamber. The cell pool was diluted to obtain approximately $5 \times 10^{5}$ cells/ $\mathrm{ml}$. The macrophage suspension was distributed in a volume of $100 \mu \mathrm{l} /$ well, through five 96 flat bottom multi-well plates, incubated at $37^{\circ} \mathrm{C}$ into a $\mathrm{CO}_{2}$ incubator for $24 \mathrm{~h}$.

\section{Spleen lymphocytes from immunized animals}

The animals were sacrificed through inhalation of ethyl ether. After the asepsis with alcohol 70GL, the spleen, removed in a chirurgical procedure, was put into a Petri dish with $5 \mathrm{~mL}$ of RPMI culture medium, without fetal serum. The spleen had the capsule displaced; the pulp was triturated into small pieces and then filtered through a thin mesh metal bolter. The lymphocytes released were transferred to a centrifuge tube with the same culture medium and left still for two minutes in order for the biggest spleen tissue blocks to precipitate. The supernatant was transferred to a new centrifuge tube and was centrifuged at $800 \mathrm{~g}$ at $4^{\circ} \mathrm{C}$ for 10 minutes. The supernatant was separated and the pellet containing the lymphocytes was resuspended in a $10 \mathrm{~mL}$ volume of RPMI culture medium without bovine fetal serum. The cells were counted in a Fuchs-Rosenthal chamber and diluted to approximately $10^{8} / \mathrm{mL}$ lymphocytes (splenocytes).

\section{Fusion procedure}

A suspension of $10^{8} / \mathrm{mL}$ of lymphocytes was added to another one containing $10^{7} / \mathrm{mL}$ of myeloma cells SP2-0, keeping a proportion of 10:1. The lymphocytes-myeloma mixture was centrifuged at $800 \mathrm{~g}$ for 10 minutes. After that, the supernatant was removed and the precipitated cells were dissolved with soft hand beats. In the sequence, $1.0 \mathrm{~mL}$ of polyethylene glycol (PEG $1450(50 \% \mathrm{w} / \mathrm{v})$, previously warmed at $37^{\circ} \mathrm{C}$, was added dropwise under continuous stirring for one minute. Then the RPMI culture medium $(1 \mathrm{~mL})$ without bovine fetal serum was added, left still for one minute and, after that, $2.0 \mathrm{~mL}$ was again added after one minute, making a total of $3.0 \mathrm{~mL}$ of cells culture medium without serum at $37^{\circ} \mathrm{C}$. Another $7.0 \mathrm{~mL}$ of medium was added for 2 minutes. Finally, $10 \mathrm{~mL}$ was added, resulting in a $20 \mathrm{~mL}$ final volume.

The suspension of fusion cells was centrifuged at $400 \mathrm{~g}$ for 5 minutes; the supernatant was removed and the cells were re-suspended in $52 \mathrm{~mL}$ of HAT cell culture medium. A $100 \mu \mathrm{L}$ of cells suspension was distributed into each well of five flat bottom plates, in which macrophages were previously grown and incubated at $37^{\circ} \mathrm{C}$ in a $\mathrm{CO}_{2}$ incubator. 
The plates were daily observed on an inverted microscope, replacing $50 \%$ of the culture medium by the $5^{\text {th }}$ day, when it was possible to observe the first hybridomal colony formation. From this stage, the medium changes took place every $48 \mathrm{~h}$ until the cellular confluence was approximately 70 to $80 \%$ (Fig 1).

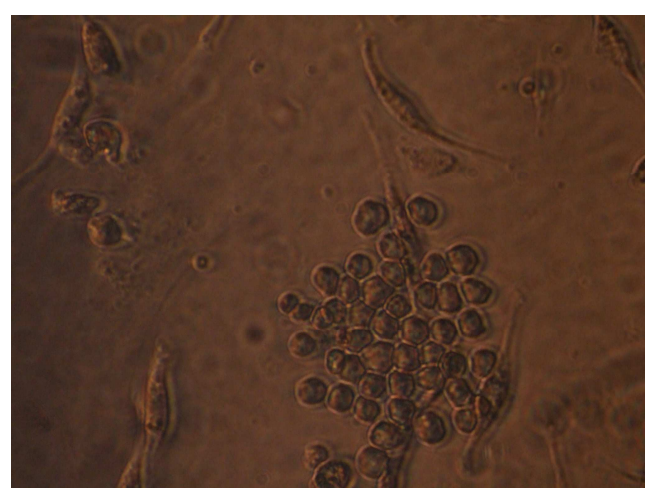

Figure 1 - Hybridoma colony formation after an incubation of seven days.

\section{ELISA screening of antibodies production}

The method used was an indirect one to detect the monoclonal antibodies anti $\operatorname{IgG}$ in hybridoma culture medium. Purified bovine $\mathrm{IgG}$ had the concentration adjusted to $1 \mathrm{mg} / \mathrm{ml}$, from which $10 \mu \mathrm{L}$ was added to $1000 \mu \mathrm{L}$ of adsorption buffer (0.2M carbonate-bicarbonate, $\mathrm{pH} 9.6)$. The final concentration, $500 \mathrm{ng}$ of proteins $/ 50 \mu \mathrm{L}$, was added to each well of an ELISA plate and incubated at $4^{\circ} \mathrm{C}$ overnight. The plates were washed with $200 \mu \mathrm{L}$ washing buffer, $8.5 \mathrm{~g}$ sodium chlorine $(\mathrm{NaCl}), \quad 0.32 \mathrm{~g}$ sodium phosphate monobasic $\left(\mathrm{NaH}_{2} \mathrm{PO}_{4}\right), \quad 110 \mathrm{~g}$ sodium phosphate dibasic $\left(\mathrm{Na}_{2} \mathrm{HPO}_{4}\right)$, and $1000 \mathrm{~mL}$ purified water; $\left.\mathrm{pH} 7.2\right)$. After that, $50 \mu \mathrm{L}$ blocking buffer was added $(3 \%$ bovine serum albumin BSA, and $0.05 \%$ Tween 20; $\mathrm{pH}$ 7.4). $50 \mu \mathrm{L}$ supernatant from each hybridoma was diluted to $1: 2$ in blocking buffer and added to each well. The plates were incubated at $37^{\circ} \mathrm{C}$ for 90 minutes. Then, the plates were washed as described before and $50 \mu \mathrm{L}$ peroxydase conjugated anti mice IgG, diluted 1:3.200, was added to each well and incubated at $37^{\circ} \mathrm{C}$ for 90 minutes. The standard washing procedure was followed and then $50 \mu \mathrm{L}$ substrate/chromogen solution was added $(400 \mathrm{mg}$ of OPD, $100 \mathrm{~mL}$ citrate buffer and $5 \mu \mathrm{l}$ hydrogen peroxide). After 15 minutes, the reaction was stopped by the addition of $50 \mu \mathrm{L} 1 \mathrm{M}$ sulfuric acid. The plates were read in a spectrophotometer at $490 \mathrm{~nm}$. H9 and H10 wells were used as negative control whereas $\mathrm{H} 11$ and H12 wells were used as positive (hyper immune serum). A check board titration of antigen and conjugate was performed before the test by diluting the antigen ( $\operatorname{IgG})$. This was performed from an initial concentration of $2 \mathrm{mg} / 50 \mu \mathrm{L}$, column 1 through 11 , and conjugate initial dilution 1:400, from row $\mathrm{A}$ to $\mathrm{H}$, base two dilutions.

\section{Fractionation of bovine immunoglobulin $\mathbf{G}$}

Bovine IgGs precipitated by the addition saturated ammonium sulphate solution, at a concentration of $33 \%$, and further purified by affinity chromatography, were submitted to an enzymatic treatment with papain. A solution of immunoglobulins was prepared with approximately $5.0 \mathrm{mg} / \mathrm{mL}$ in a $10 \mathrm{mM}$ sodium acetate solution, $\mathrm{pH}$ 5.5. A stock solution of cysteine $1 \mathrm{M}$ was added to $1 / 20$ of the original volume and the same procedure was carried out with $20 \mathrm{mM}$ EDTA stock solution. For each milligram of antibody, $10 \mathrm{mg}$ of papain was added. The solution was incubated at $37^{\circ} \mathrm{C}$ in water-bath for $16 \mathrm{~h}$. After that, iodocetamide was added to a final concentration of $75 \mathrm{mM}$ and incubated again for 30 minutes at room temperature. The obtained fragments were submitted to SDS-PAGE electrophoresis and the proteins were transferred to a Western Blot nitrocellulose membrane. Monoclonal antibodies were added to confirm their reactivity and specificity to bovine IgG-Fc fragment (crystallizable fragments). The secretor clones of immunoglobulins anti bovine $\mathrm{IgG}-\mathrm{Fc}$ were used as inputs to produce bovine disease diagnostics (Fig 2). 


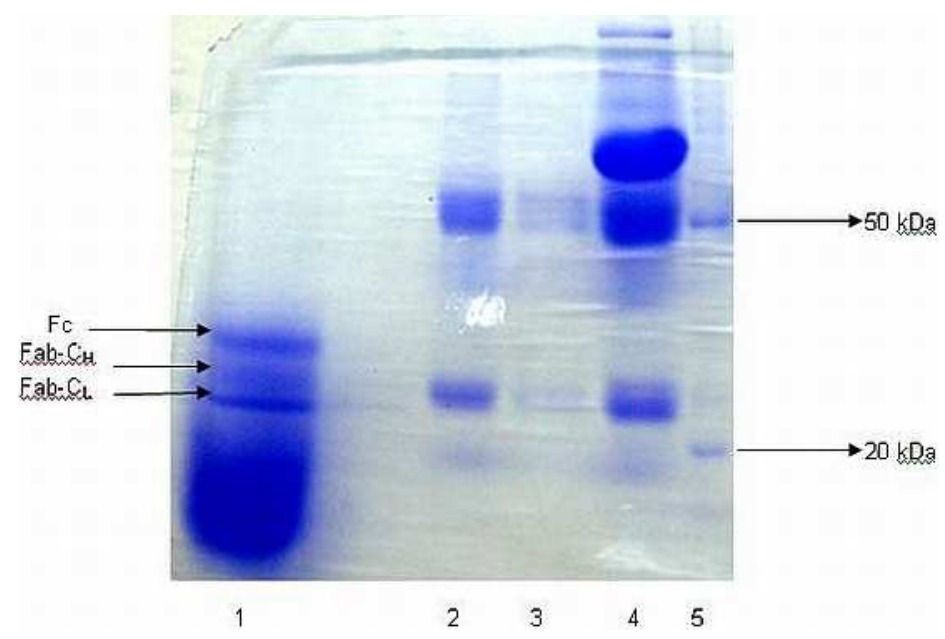

Figure 2 - SDS-PAGE gel at $10 \%$ after being fractioned with papain. 1) Fragmented sample of $\mathrm{C}_{\mathrm{L}}$ and $\mathrm{C}_{\mathrm{H}} \mathrm{Fab}$ and $\mathrm{Fc}$ of purified bovine IgG; 2) Purified bovine $\mathrm{IgG}$; 3) Semi purified bovine IgG; 4) Bovine serum; 5) Molecular mass marker.

\section{Bovine IgG characterization through SDS- PAGE and western blot}

The samples of the bovine serum, unpurified IgG and purified $\operatorname{IgG}$ (by chromatography) were submitted to electrophoresis SDS-PAGE and Western Blot. Samples had the concentration of the proteins initially adjusted in order to get $150 \mu \mathrm{g}$ into $25 \mu \mathrm{l}$ sample buffer $(4.0 \mathrm{~mL}$ of $1 \mathrm{M}$ Tris $\mathrm{pH} \quad 8.0 ; 4.0 \mathrm{~mL}$ glycerol $100 \% ; 0.2 \mathrm{~mL} 0.5 \mathrm{M}$ EDTA; $0.4 \mathrm{~mL}$ bromophenol blue $1 \% ; 11.4 \mathrm{~mL}$ purified water; $5 \%$ mercaptoetanol). The samples were boiled for 5 minutes and applied to the gel. Also, the molecular mass markers Bench Marck and Magic Marck, Amershan brand, with molecular masses ranging from 20 to $220 \mathrm{KDa}$, were applied without having been boiled.

To perform the SDS-PAGE, the standard procedure was used with continuous system and $15 \%$ acrilamide bis-acrilamide concentration in the separating gel $(7.5 \mathrm{~mL}$ acrilamide bisacrilamide 30:0.8; $2.1 \mathrm{~mL} 1 \mathrm{M}$ Tris- $\mathrm{HCl}, \mathrm{pH} 8.8$, $150 \mu \mathrm{L} \quad 10 \%$ SDS, $37 \mu \mathrm{L} \quad 20 \%$ ammonium persulfate, $7.5 \mu \mathrm{L}$ Temed; $5.2 \mathrm{~mL}$ purified water). The $5 \%$ stacking gel was made of $2.5 \mathrm{~mL}$ acrilamide bis-acrilamide 30:0.8; $1 \mathrm{M}$ Tris- $\mathrm{HCl}$, pH 6.8; $150 \mu \mathrm{L}$ SDS $10 \% ; 37 \mu \mathrm{L} 20 \%$ ammonium persulfate; $7.5 \mu \mathrm{L}$ Temed; $11.3 \mathrm{~mL}$ purified water. The running buffer used was tris-glycine (stock solution : $30.3 \mathrm{~g}$ tris-base; $144 \mathrm{~g}$ glycine; $5 \mathrm{~g}$ SDS; $1000 \mathrm{~mL}$ purified water; $\mathrm{pH}$ 8.6). Use solution:
$100 \mathrm{~mL}$ stock, $900 \mathrm{~mL}$ purified water) and the migration occurred at $70 \mathrm{~V}$ per minute. Finally, the gel was stained with coomassie blue R250 $(0.1 \mathrm{~mL}$ coomassie blue; $45 \mathrm{~mL}$ methanol; $10 \mathrm{~mL}$ acetic acid; $45 \mathrm{~mL}$ purified water) for 60 minutes and destained $(4 \mathrm{~mL}$ methanol; $7.5 \mathrm{~mL}$ acetic acid; $3 \mathrm{~mL}$ purified water) for 60 minutes (Fig.3).

From a second gel, proteins were transferred to the nitrocellulose membrane applying 20 to $30 \mathrm{~V}$, overnight at $4^{\circ} \mathrm{C}$. In the next step, the membranes were blocked (blocking solution: $0.02 \mathrm{~g}$ bovine albumin fraction $\mathrm{V}, 100$ purified water), under stirring for 90 minutes. Monoclonal antibody anti bovine $\operatorname{IgG}$ was diluted to $1: 2$, added to nitrocellulose stripes and incubated for 90 minutes at $37^{\circ} \mathrm{C}$. The membranes were washed 5 times with the washing buffer and the peroxidase conjugated anti mice $\mathrm{IgG}$ added at a dilution of $1: 1000$ and incubated for 90 minutes at $37^{\circ} \mathrm{C}$. The membranes were washed 5 times with the washing buffer and the chromogen-substrate was added $(0.67 \mathrm{~mL}$ 4-chloro-1-naftol, $10 \mathrm{~mL} \quad 0.1 \mathrm{M}$ sodium acetate, $10 \mathrm{ul}$ hydrogen peroxide, $\mathrm{pH}$ 5.2) and remained for 15 minutes (Fig 4).

Papain digestion of bovine $\operatorname{IgG}$ generated three fragments with molecular masses around $25 \mathrm{kDa}$. The heaviest $\mathrm{Fc}$ fragment was the only one to which the monoclonal antibody $\mathrm{B} 3 \mathrm{H} 12$ was bound, revealed by color development on the western blot membrane (Fig 4). 


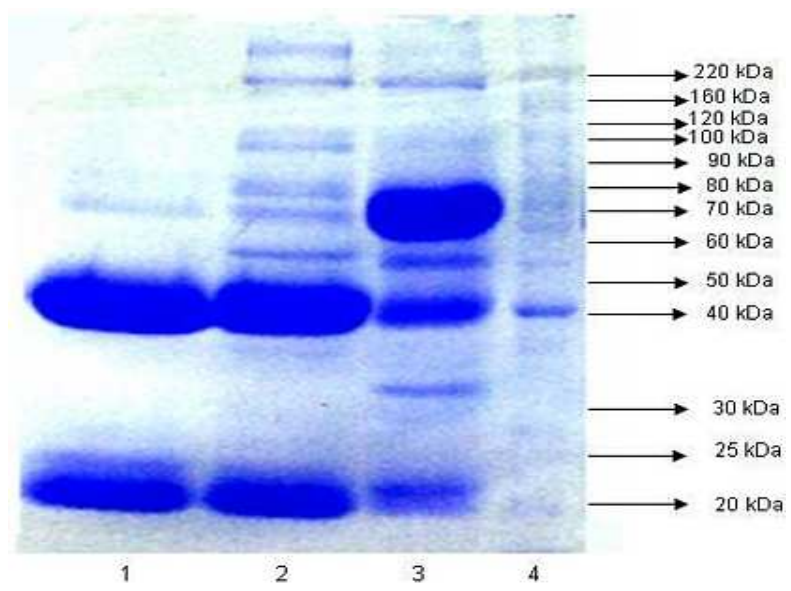

Figure 3 - SDS-PAGE Gel at $10 \%$. 1) Purified bovine $\mathrm{IgG} ; 2$ ) Semi purified bovine $\operatorname{IgG}(33 \%$ SAS); 3) Bovine serum; 4) Molecular mass marker, with the obtaining of the heavy chains bands at the 50KDa band and the light chains at the band with $25 \mathrm{KDa}$.

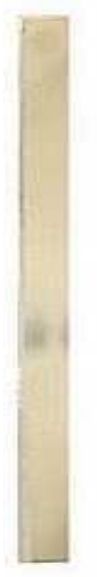

1

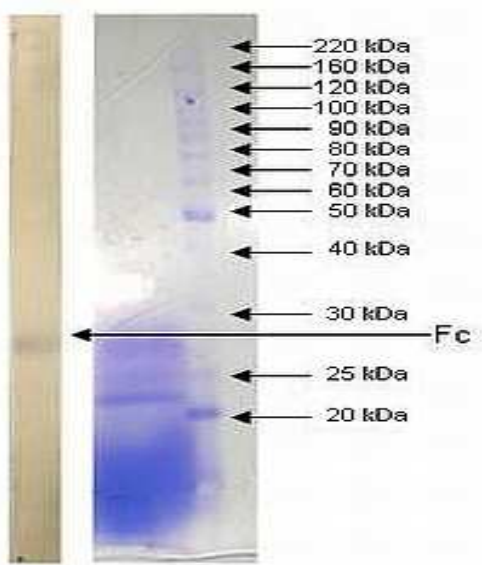

3

Figure 4 - Result of the Western Blot test. 1 and 2) Fc fragments of bovine IgG after 16 hours with papain digestion 3) Molecular mass marker.

\section{RESULTS AND DISCUSSION}

The samples of bovine $\operatorname{IgG}$ purified by affinity chromatography and quantified by spectrophotometer with absorption of ultra-violet rays showed concentrations that oscillated between 2.2 to $3.6 \mathrm{mg} / \mathrm{mL}$. Considering the fixed retaining capacity of the columns $(25 \mathrm{mg} / \mathrm{mL})$, around which the IgG concentration in bovine serum oscillated, and the standard protocol followed in all the purification procedures, the variations registered in the concentration could be attributed to different affinity levels of the protein $G$ for different subclasses of $\mathrm{IgG}$, since the used serum constituted in a pool of harvests from different animals.

The purification was preceded by precipitation with ammonium sulfate (final concentration of $33 \%$ ), allowing an $\mathrm{IgG}$ concentration $(\mathrm{mg} / \mathrm{mL})$ much higher than the column retaining capacity. The obtained samples that were used through the immunization protocols were submitted to polyacrylamide gel electrophoresis with reducing agent in order to separate heavy and light chains, where it was possible to observe the presence of bands with molecular masses equivalent to $25 \mathrm{KDa}$ and $50 \mathrm{KDa}$, related to the light and heavy chains, respectively (Harlow et al., 1988). It was also 
possible to determine the purity grade from the obtained samples. Despite the staining method uses coomassie blue as dye, which allowed the detection of proteins in concentrations from 1.0 to $2.2 \mu \mathrm{g} / \mathrm{mL}$, there were not any extra bands, except for those pertaining to the subject under study.

The purity grade of samples has relative importance to the immunization process of animals, because from the generated hybridomas it is possible to screen those that secrete anti bovine IgG. However, considering that the bovine IgGs used for the immunization would be the same used in the ELISA plates sensitization, which would be used in the selection processes of the anti $\mathrm{IgG}$ clones, special caution was taken to make the samples as pure as possible. We did consider the possibility of mice immunizations with pure $\mathrm{Fc}$ fragment, but taking in account the changes in the conformation and epitope destruction, we decided in favor of the whole molecule.

At the end of the immunization protocol, the mice were evaluated for their humoral response for bovine $\mathrm{IgG}$. The chosen evaluation method was the immunodiffusion in agar gel. Blood serum samples obtained by cardiac punction of the mice were evaluated against purified $\mathrm{IgG}$ in the immunodiffusion tests. After an incubation period of $48 \mathrm{~h}$, it was possible to see the immunoprecipitation lines between the immunized mice serum and purified $\mathrm{IgG}$, and absence of lines when the serum of non-immune mice was used. That was a reaction which made it possible to understand that intense and clear precipitation lines were convincing evidence that the mice spleen had significant quantities of clones of sensitized B lymphocytes. Inherent to the immunodiffusion methodology is its high specificity and low sensitivity, since it only detects the large protein quantities ( 3 to $20 \mu \mathrm{g} / \mathrm{mL}$ ). The present work revealed intense precipitation lines, which showed that the animals were ready for fusion.

Out of a total of five 96-well plates, 125 wells had the presence of hybridomas colonies in which, when 70 to $80 \%$ of the well surface was reached, the supernatants were removed and submitted to ELISA test to evaluate the antibodies secretion anti bovine IgG. Seven clones with expressive optical density were expanded and kept into liquid nitrogen. The $25 \%$ of yeld was not significant, suggesting that the fusion protocol needed improving.
For standardization of the ELISA test, a Checkboard titration was performed in which antigen was diluted from an initial concentration of $2 \mathrm{ug}$, in the first row, pursuing base two dilutions until the eleventh. The conjugated was also diluted in the same ground, beginning with a dilution of 1:800 used in the columns. By using the antigen concentration of $32 \mathrm{ng}$ per well and conjugated diluted to 1:3.200, good performance, no color development in negative control wells and optical densities compatible with the positive control were observed in the wells containing secretor clones. From the set of reagent clones in ELISA, two named $\mathrm{B} 4 \mathrm{~F} 11$ and $\mathrm{B} 3 \mathrm{H} 12$ were selected for the diagnostic reagent production activities. The choice was based on cellular biology criteria, such as colony growth efficiency "in vitro", duplication time and optical density obtained with supernatants. The monoclonal antibodies produced by these clones were evaluated by immunodiffusion to know whether they were able to produce precipitation or not. Previous experiments with anti-species monoclonal antibodies also revealed to have no precipitation capacity (Letesson et al., 1985). The possible explanation lies in the molecular mass of the target molecule, bovine IgG, which has $190 \mathrm{KDa}$, and the largest angle possibly formed by the Fab chains would not allow the bridge formation between two juxtaposed molecules.

Bovine IgG subclasses have been submitted to the enzymatic digestion using different enzymes such as papain, pepsin and trypsin. According to the cleavage site, enzymatic kinetics and incubation period, they produce peptides with different molecular masses, which make the basis for delineation of experimental purpose (Butler, 1986). To ensure that the monoclonal antibodies reacted certainly with $\mathrm{Fc}$ region of bovine $\mathrm{IgG}$, papain was chosen in the present work, since it generated fragments almost equal to different $\mathrm{IgG}$ subclasses. Initial digestion period of $4 \mathrm{~h}$ at $37^{\circ} \mathrm{C}$ generated no detectable fragments when submitted to electrophoresis, but when this incubation period was raised to $16 \mathrm{~h}$ at the same temperature, the cleavage experiment generated three bands of approximately $25 \mathrm{KDa}$. After transferring to the nitrocellulose membrane, the gel proteins were sequentially incubated with monoclonal antibodies, peroxydase conjugated, and lastly substrate-chromogen. The results generated assured the specific reactivity of antibodies 
produced by $\mathrm{B} 3 \mathrm{H} 12$ clone within the $\mathrm{Fc}$ region of bovine IgG. Regarding the second clone (B4F11), the same was not possible, probably due to the nature of the target antigen, which was conformation dependent.

The fragments generated by the proteolysis and submitted to electrophoresis, with reducing agent, produced a pattern of bands that were ordinated by small molecular mass differences. In such order, proteins with the lowest molecular masses are placed close to the end of the migratory path. In the present case, the immunoglobulin light chains were preceded by a band of heavy chain and at the end by the fragment $\mathrm{Fc}$ band. Considering the lack of molecular mass markers that would produce bands with smaller weight differences, and due to the fact that two batches of markers used here were inefficient regarding the nitrocellulose transfer (though they had been previously chosen due to their specifications for Western Blot), there was no other alternative but established an equivalence in $\mathrm{mm}$, the distance between the band position and the gel final extremity. The stained band on the Blot membrane was compared to those from the gel. Concerning the monoclonal antibody B4F11, there was no noticeable reaction with any of the fragments, which showed that this kind of antibody was taken to an antigen epitope, which was disarranged when there was chain separation by the breaking of intra and intermolecular disulfide bridges. It is relevant to state that this hybridoma presents excellent growth performance and has a good antibody production level, as evidenced by the optical density level in ELISA.

This work tried to expose the relevance of good quality diagnostic reagent production for the infectious and parasitic diseases of animals. To the best of our knowledge, this kind of reagents has never been produced before in this country. This would set the basis to develop a series of tagged antibodies for diagnostic purpose. Ideally, one should pursuit immunizations to produce subclass specific monoclonal antibodies, which would demand different protocols of purifications and characterizations. It is also important to consider the possibility of generating anti-ruminant monoclonal antibodies from immunization with bovine IgG.

The chosen clone for reagent elaboration was the $\mathrm{B} 3 \mathrm{H} 12$, which should be evaluated for the real possibility to react with $\mathrm{IgG}$ from others ruminant species in the next researches. The characterization of which segment of the heavy chain the produced antibody interacted must be given equal importance, which could be used to study the isotopes, $\mathrm{IgG}$ quantification, $\mathrm{Fc}$ binding of bacterial proteins implicated in the evasion of the immune system, and the possibility of this antibody to be specific for glycoproteic epitopes.

\section{RESUMO}

No Brasil, anticorpos anti-espécie específica usados em métodos de diagnóstico geralmente são importados, aumentando o custo das análises. Visando produzir insumos para métodos diagnóstico por enzimaimunoensaio, o presente trabalho teve como objetivo produzir e caracterizar anticorpos monoclonais anti imunoglobulina $G$ (IgG) bovina. De sete hibridomas obtidos e que apresentaram valores relevantes de absorbância em teste imunoenzimático (ELISA indireta), dois clones com melhor performance foram selecionados e designados B4F11 e B3H12. Estes anticorpos monoclonais foram analisados em Western Blot para reatividade com fragmentos de IgG bovina, obtidos por proteólise com papaína e separados por eletroforese em gel de poliacrilamida, com presença do agente redutor beta-mercaptoetanol. A eletroforese mostrou que o anticorpo B4F11, foi direcionado para um antígeno conformacional, e que o monoclonal $\mathrm{B} 3 \mathrm{H} 12$ reagiu especificamente com a porção $\mathrm{Fc}$ da IgG bovina (fragmento cristalizável). Este anticorpo será utilizado no desenvolvimento de reagentes para imunoensaios de interesse à pesquisa e diagnósticos.

\section{REFERENCES}

Purification of Specific Groups of Molecules, Affinity Chromatography, Principle and Methods. Amersham Pharmacia Biotechnology, Edition AB 18-1020-90, Chapter 3, 32-39.

Bastida-Corkuera, F.D.; Butler, J.E.; Yahiro, S. and Corbeil, L.B. (1999a), Differential complement activation by bovine IgG2 allotypes. Veterinary Immunology and Immunophatology, 71, 115-123.

Bastida-Corkuera, F.D.; Nielsen, K.H. and Corbeil, L.B. (1999b), Binding of bovine $\operatorname{IgG}^{\mathrm{a}}$ and $\mathrm{IgG}^{\mathrm{b}}$ allotypes to protein $\mathrm{A}$, protein $\mathrm{G}$, and Haemophilus somnus IgBPs. Veterinary Immunology and Immunophatology, 71, 143-149. 
Blakeslee D.; Rapcz J. and Butler JE. (1971), Bovine immunoglobulin allotypes, Journal of Dairy Science, 54, 1319-1320.

Brandon M.R.; Watson D.L. and Lascelles A.K. (1971). The mechanism of transfer of immunoglobulin into mammary secretions of cows. Australian Journal of Experimental Biology and Medical Science, 49, 613623.

Butler, J.E; Maxwel, C.F.; Pierce, C.S.; Hylton, M.B.; Asofsky, R. and Kiddy, C.A. (1972), Studies on the relative synthesis on distribuition of $\operatorname{IgA}$ and $\operatorname{IgG} 1$ in various tissue and body fluds of the cow. Journal of Immunology, 109, 38-46.

Butler, J.E. (1974), Immunoglobulins of the mammary secretions. In-Larson B.L. and Smith, V. eds. Lactation, A Comprehensive Treatise, Chapter V. New York, Academic Press, 217-55.

Butler, J.E, (1986), Biochemistry and Biology of Ruminant Immunoglobulins. In-Pandey R., eds. Progress in Veterinary Microbiology and Immunology, 2. Basel: Karger, 1-53. Microbiology and Immunology, 2, 1-53.

Corbeil, L.B.; Gogolewski, R.P.; Kacskovics, I.; Nielsen, K.H.; Corbeil, R.R.; Morrill, J.L.; Greenwood, R. and Butler, J.E. (1997), Bovine IgG2a antibodies to Haemophilus somnus and allotype expression. Canadian Journal Veterinary Medice, 61, 207-213.

Dyxon, F.J.; Weigle, W.O. and Vasques, J.J. (1961), Metabolism and mammary secretions of serum protein in the cow. Laboratory Investigation, 10, 216237.

Guidry, A.J.; Butler, J.E.; Person, R.B. and Weinland, B.T. (1980), IgA, IgG1, IgG2, IgM and BSA in serum and mammary secretion throughout lactation. Veterinary Immunology and Immunopathology, 1, 329-341.

Gu, F.; Chowdhary, B.P.; Andersson, L.; Harbitz, I. and Gustavysson, I. (1992), Assignment of the bovine immunoglobulin gamma heavy chain (IGHG) gene to chromosome $21 \mathrm{q} 24$ by in situ hybridization. Hereditas, 117, 237-240.

Harlow, E. D. and Lane, D. (1988), Antibodies. A Laboratory Manual, NY: Cold Spring Harbor Laboratory Press.

Jerne, N.K. (1984), The generative grammar of the immune system. Nobelprize Organization, Nobel lecture, Physiology or Medicine.

Kackskovics, I. and Butler, J.E. (1996), The heterogeneity of bovine IgG2. The complete cDNA sequence of bovine IgG2a (A2) and IgG1. Molecular Immunology, 33, 2, 189-195.

Kackskovics, I. (2004), Fc receptors in liverstock species, mini-revew. Veterinary Immunology and Immunophatology, 102, 351-362.

Kehoe, J. M. and Capra, J.D. (1974), Nature and significance of immunoglobulin subclasses. New York State Journal of Medicine, 74, 489-491.
Kemler, R.; Mossmam, H.; Strohmaier, U.; Kickhöten, B. and Hammer, D.K. (1975), In vitro studies on the selective binding of IgG from different species to tissue sections of the bovine mammary gland. European Journal of Immunology, 5, 603-608.

Knight, K.I.; Suter, M. and Becker, R.S. (1988), Genetic engineering of cattle Ig. Construction and characterization of hapten-binding cattle/murine chimeric $\operatorname{IgE}, \operatorname{Ig} \mathrm{A}, \operatorname{IgG} 1, \operatorname{IgG} 2$ and $\mathrm{IgG} 3$ molecules. Journal of Immunology, 140, 3654-9.

Letesson, J.J.; Lostrie-Trussant, N. and Depelchin, A. (1985), Production d'anticorps monoclonaux specifiques d'isotypes d' immunoglulines bovines. Annales Médécine Vétérinaire, 129, 131-141.

Martinez, J.; Tomás, G.; Merino, S.; Arriero, E. and Moreno, J. (2003), Detection of serum immunoglobulins in wild birds by direct ELISA: a methodological study to validate the technique in different species using antichicken antibodies, Funcional Ecology, 17, 700-706.

Mcguire, T.; Musoke, A. J. and Kurtti T. (1979), Functional properties of bovine $\operatorname{IgG} 1$ and $\operatorname{IgG} 2$ : interaction with complement macrophages, neutrophils and skin. Immunology, 39, 249-256.

Milstein, C. (1984), From the structure of antibodies to the diversification of the immune response. Nobelprize, Nobel Lecture, Physiology or Medicine.

Nakane, P.K. and Kawaoi, A. (1974), Peroxidaselabeled antibody a new method of conjugation. The Journal of Histochemistry and Cytochemistry, 22, 12, 1084-1091.

Pastoret, P.P. (1998), Immunology of Catle, chapter VIII. In-Handbook of Vertebrate Immunology Academic Press.

Rabbani, H.; Brown, W.R.; Butler, J.E. and Hammarström L. (1997), Polymorphism of the IGHG3 gene in cattle. Immunogenetics, 46, 326-331.

Rapcz, J. and Hasler-Rapacz, J. (1978) r1-globulinallotype $\mathrm{C} 1$ in cattle. Animal Blood Groups Biochemistry and Genetics, 9, 59-63.

Saini, S.S.; Farrugia, W.; Muthusamy, N.; Ramsland, P.A. and Kaushik, A.K. (2007), Structural evidence for a new IgG1 antibody sequence allele of cattle. Scandinavian Journal of Immunology, 65, 1, p.32-38.

Symons, D.B.A.; Clarkson, C.A. and Beale, D. (1989), Structure of bovine immunoglobulin constant region heavy chain gamma 1 and gamma 2 genes. Molecular Immunology, 26, 9, 841-850.

Wegrezyn, J.A. and Wegrezyn, Z. (1978), Allelism of genes determining two IgG1 allotypes in cattle. Animal Blood Group Biochemistry and Genetics, 9, 59-63.

Received: October 26, 2007; Revised: February 27, 2008; Accepted: November 11, 2009. 